Conservation Biology of Freshwater Turtles and Tortoises:

\title{
Graptemys ouachitensis Cagle 1953 - Ouachita Map Turtle
}

\author{
RichaRd C. Vogt ${ }^{1}$ \\ ${ }^{1}$ Coordinaçao de Biodiversidade, Instituto Nacional de Pesquisas da Amazônia, \\ 2936 Av. André Araújo, Petrópolis, CEP 69.067-375, Manaus, Amazonas, Brazil \\ [vogt@inpa.gov.br; dickturtlevogt@gmail.com]
}

Summary.-The Ouachita Map Turtle, Graptemys ouachitensis (Family Emydidae), is a mediumsized river turtle (carapace length to $160 \mathrm{~mm}$ in males, $260 \mathrm{~mm}$ in females) common in large rivers and oxbow lakes in areas of moderate to rapid current, primarily within the Mississippi River drainage of the central United States. Ouachita Map Turtles prefer large clear water rivers, males are more likely to be found in areas with strong current, while females can often be found feeding in backwater areas; they are known to hibernate behind wing dams in the Mississippi River. Some individuals may have a wide complete postorbital crescent separating the orbit from the lateral neck stripes; this crescent may be broken with or without one to four stripes entering into contact with the orbit. The under surface of the head is characterized by four prominent bright yellow spots, one on each mandible, one at the jaw symphysis, and another in the gular region. There is a low keel on the carapace. The species is omnivorous, feeding on a wide variety of aquatic plants, as well as aquatic insects. The Ouachita Map Turtle, like all species of Graptemys, is listed in CITES Appendix III, which offers no protection, but requires documentation of how many are exported internationally. Population and ecological studies have found this species to be abundant in many localities throughout its range; no specific conservation or management practices need be adopted for the widespread subspecies G. o. ouachitensis at this time, though population monitoring of the restricted subspecies $G$. o. sabinensis is recommended.

Distribution. - USA. Graptemys ouachitensis occurs from the Mississippi River in Wisconsin and Minnesota east into Indiana, Ohio, and West Virginia, and south in the Mississippi River Basin through Louisiana, west to Oklahoma and Kansas, and south to eastern Texas.

Synonymy.-Graptemys pseudogeographicaouachitensis Cagle 1953,Malaclemyspseudogeographica ouachitensis, Graptemys ouachitensis, Graptemys ouachitensis ouachitensis.

SubSPECIES. - Two are recognized in this account: 1) Graptemys ouachitensis ouachitensis Cagle 1953 (Ouachita Map Turtle) (distribution: from Wisconsin and Minnesota east into Indiana, Ohio, and West Virginia, and south through eastern Louisiana and west to Oklahoma and Kansas); and 2) Graptemys ouachitensis sabinensis Cagle 1953 (Sabine Map Turtle) (distribution: Sabine-Neches, Calcasieu, and Mermantau river drainages of southwestern Louisiana and eastern Texas) (synonymy: Malacoclemmys intermedia Baur in Beyer 1900 (nomen nudum), Graptemys intermedia, Graptemys pseudogeographica sabinensis Cagle 1953, Malaclemys pseudogeographica sabinensis, Graptemys ouachitensis sabinensis, Graptemys sabinensis).

Status. - IUCN 2018 Red List: Least Concern (LC, assessed 2011); CITES: Appendix III (USA) as Graptemys spp.; US ESA: Special Concern.

Taxonomy. - This species was originally considered to be a subspecies of the False Map Turtle when it was described as Graptemys pseudogeographica ouachitensis by Cagle (1953). The type locality is the Ouachita River, 4 miles northeast of Harrisonburg, Louisiana, USA, and the holotype, UMMZ 104345, was collected by A.H. Chaney and C.L. Smith in 1950. For a short time the taxon was listed under the name Malaclemys pseudogeographica ouachitensis (Cochran and Goin 1970). Vogt (1974, 1978) was the first to recognize this form as a species distinct from
G. pseudogeographica, and considered the species to have two subspecies: the northern more widespread taxon, G. $o$. ouachitensis, and G.o. sabinensis (Cagle 1953), restricted to rivers in southwestern Louisiana and eastern Texas. This followed Cagle's (1953) original description of these taxa as subspecies.

Allozymes depicted by horizontal starch gel electrophoresis did not separate these two subspecies (Vogt 1979, 1993a, 1995). Recently, the Sabine Map Turtle (G.o. sabinensis) has been elevated to species status (Lindeman 


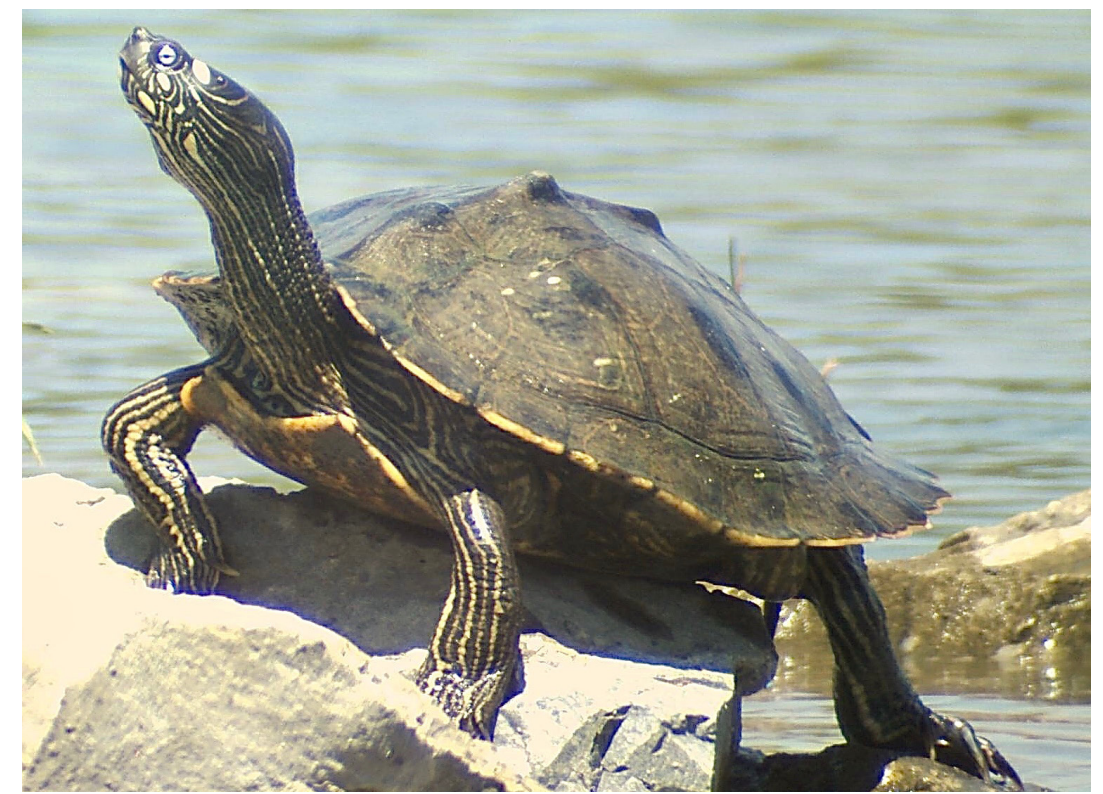

Figure 1. Graptemys ouachitensis ouachitensis, Paris Landing State Park, Henry Co., Tennessee, USA. Photo by P.V. Lindeman.

2013), basically because it has a distinct allopatric range; however, some individuals in the population have identical head markings to the Ouachita Map Turtle (G. o. ouachitensis), including individuals in the type series, so the validity of recognizing this disjunct population as a separate species needs a more detailed phylogenetic study (Vogt 1978, 1993a, 1995; TTWG 2017). Other studies suggest that $G$. sabinensis is a species distinct from G. ouachitensis (Stephens and Wiens 2003, 2009c; Meyers 2008; Wiens et al. 2010; Brown et al. 2012).

Though debate exists whether sabinensis should or should not be recognized as a separate species, it is my opinion that it represents a subspecies. The characteristics of sabinensis appear in a low percentage in populations of ouachitensis, and $5 \%$ of the individuals of sabinensis examined from the Sabine River itself have the characteristics assigned to ouachitensis (Vogt, unpubl. data). In addition, neither the courtship display nor the ecology of these

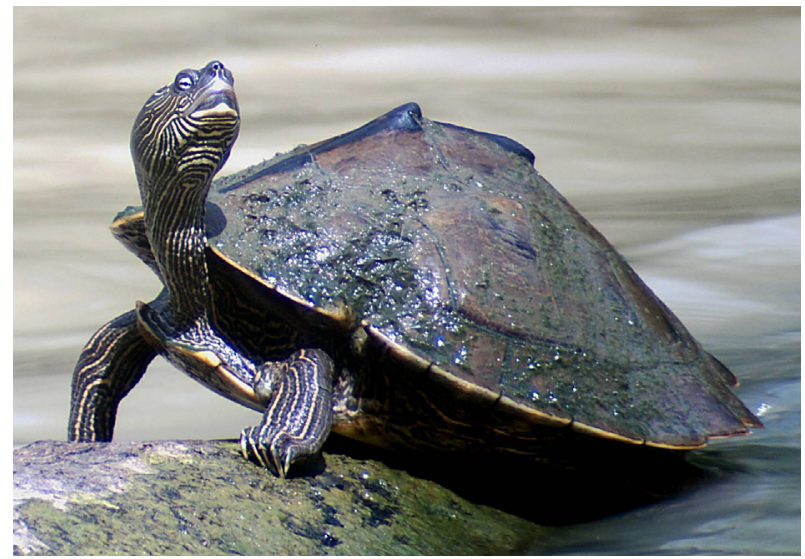

Figure 2. Graptemys ouachitensis sabinensis, nr. Estherwood, Acadia Parish, Louisiana, USA. Photo by P.V. Lindeman. subspecies appear to differ, nor can they be separated by electrophoretic differences (Vogt 1978, 1993a).

Phylogenetically, G.ouachitensis is most closely related to G. pseudogeographica (Lamb et al. 1994; Praschag et al. 2017; Thomson et al. 2018). It is known to naturally hybridize with both that species and Graptemys geographica in the Mississippi River in Wisconsin (Vogt 1978, 1993a). However, the only ouachitensis x geographica hybrid found nesting in this area did not produce fertile eggs from either her clutch in nature or in six other clutches produced when she had access to males of both species while in captivity (Vogt 1980a; Vogt, unpubl. data).

Praschag et al. (2017), based on mitochondrial and nuclear DNA, concluded that $G$. ouachitensis and $G$. pseudogeographica are a single species, and that the entire genus Graptemys is overly split. Thomson et al. (2018) disagreed and presented a comprehensive phylogeny of Graptemys based on 18 nuclear genes and 2 mitochondrial

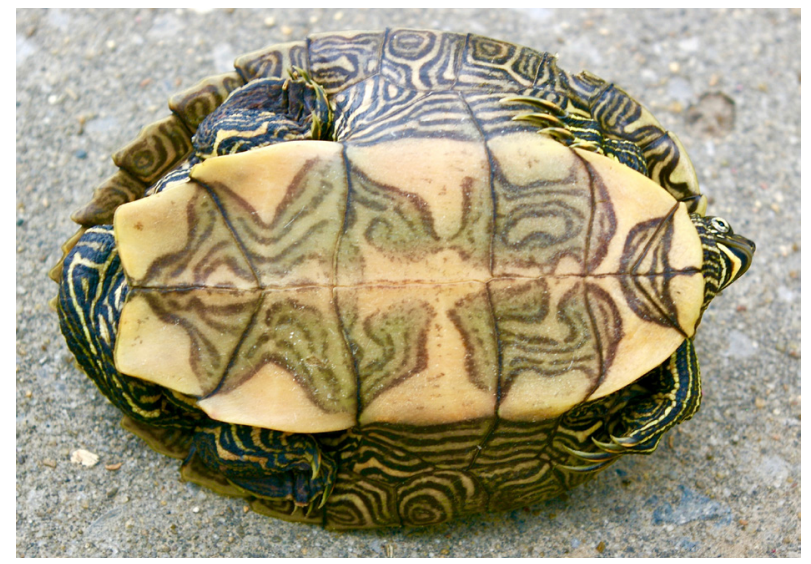

Figure 3. Graptemys ouachitensis sabinensis, Calcasieu River, Louisiana, USA. Photo by P.V. Lindeman. 
genes. Using both phylogeny and divergence times with a molecular clock under a coalescent framework, they suggested that diversification has been more recent and more rapid than suspected from other studies. Their study demonstrated unresolved divergence between G.ouachitensis (two subspecies) and G.pseudogeographica (two subspecies), but they retained them as closely related species. They noted that G.o.sabinensis was the most divergent lineage among these four subspecies, consistent with its recognition as a separate species by Lindeman (2013).

Description. - The Ouachita Map Turtle, Graptemys o. ouachitensis is a medium-sized river turtle; females are larger at 120-260 mm carapace length and males smaller at 90-160 mm. The carapace is elevated with low black knobs on the second, third, and fourth vertebrals. The plastron is flat. The carapace is green to olive with 1 to 6 (usually 1) black blotches on the posterior edge of each scute. These

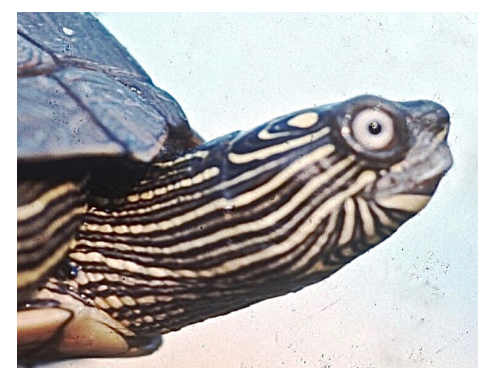

Figure 4. Graptemys ouachitensis sabinensis, Sabine River, nr. Many, Louisiana, USA. Photo by R.C. Vogt.

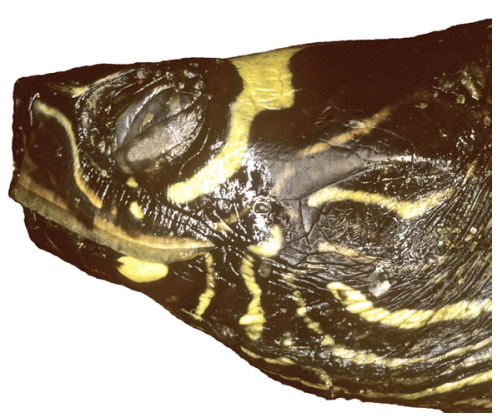

Figure 5. Graptemys ouachitensis ouachitensis, Stoddard, Vernon Co., Mississippi River, Wisconsin, USA. Photo by R.C. Vogt.

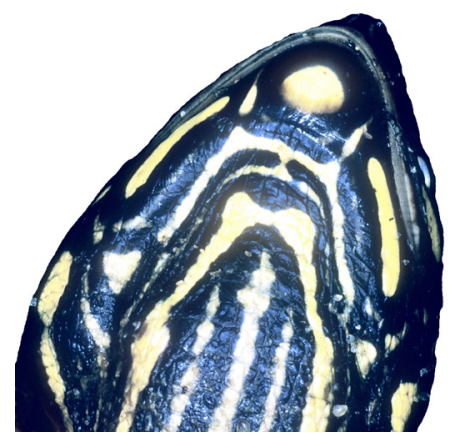

Figure 6. Graptemys ouachitensis ouachitensis, Stoddard, Vernon Co., Mississippi River, Wisconsin, USA. Photo by R.C. Vogt. blotches are encircled with yellow or orange rings forming ocelli, or a lattice of interconnected circles may be present without black blotches. This pattern is often faded in adult females, and complete melanism of the carapace is frequent in northern populations.

The plastron is yellow or cream, marked with concentric swirls of dark green; the swirls primarily follow the scute sutures and cover less than $60 \%$ of the plastron. This pattern fades to a mottling of brown on yellow in adult females with dark lines along the sutures.

The head is dark green with yellow markings, never orange as in some populations of G. pseudogeographica. A suborbital large blotch extends posteriorly to meet a pair of longitudinal narrower lines running the length of the head. This wide "crescent" is usually broken behind the eye and may have from 1 to 4 wide yellow lines in contact with the orbit and a large yellow spot below the eye. Incubation

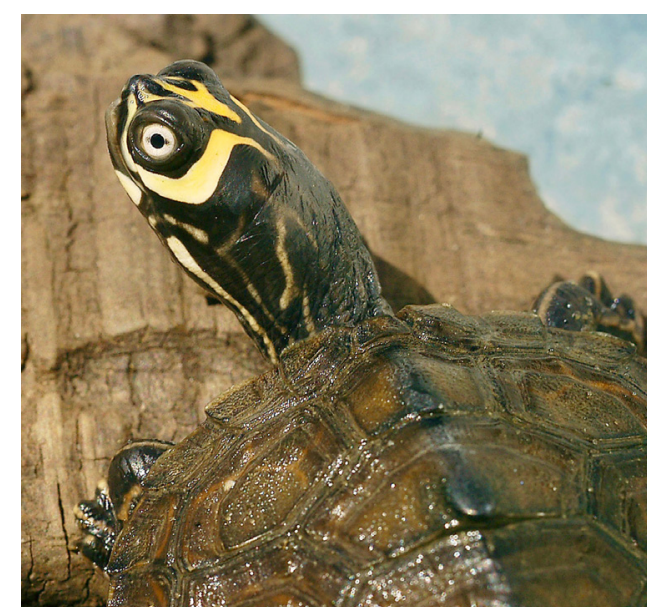

Figure 7. Graptemys ouachitensis ouachitensis, Mississippi River, Minnesota, USA. Photo by B. Brecke.

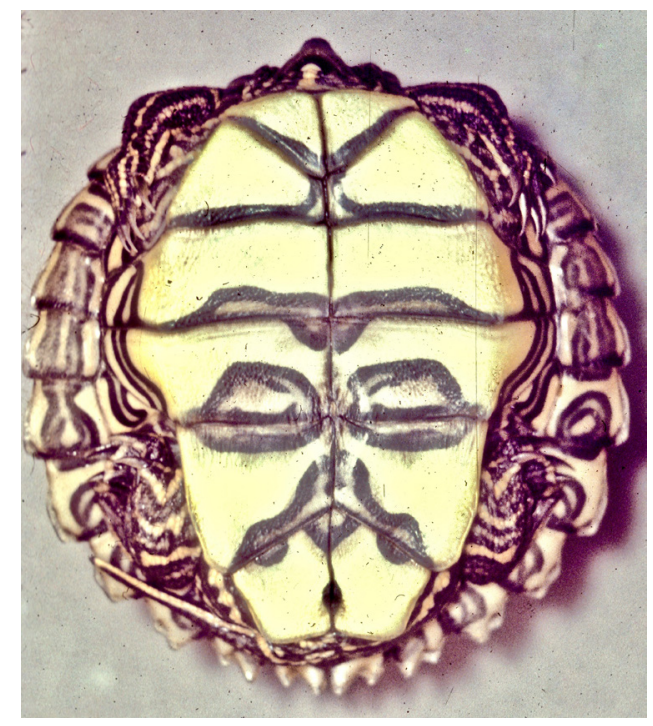

Figure 8. Graptemys ouachitensis ouachitensis hatchling, Stoddard, Vernon Co., Mississippi River, Wisconsin, USA. Photo by R.C. Vogt. 


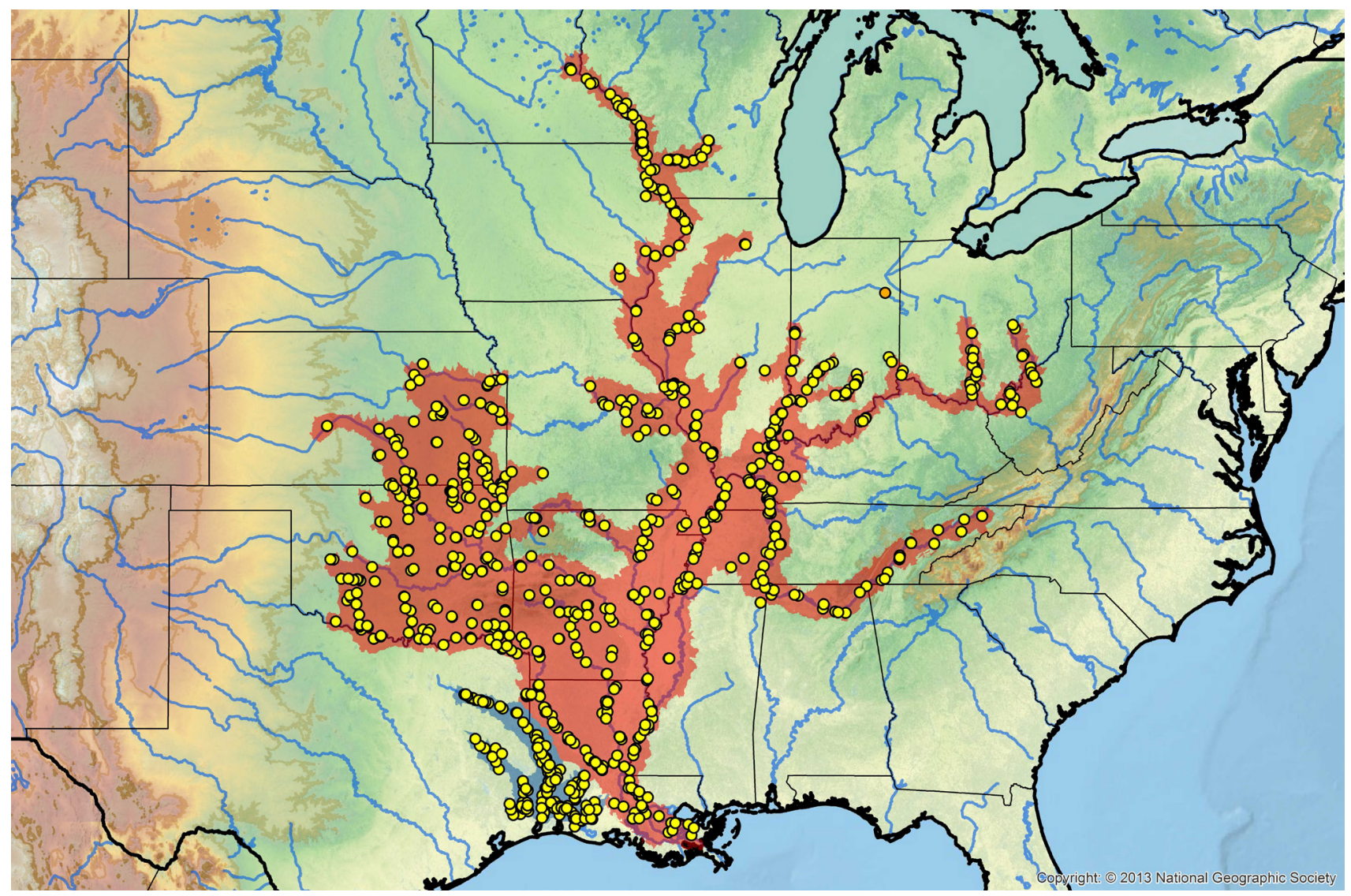

Figure 9. Historic distribution of Graptemys ouachitensis in central and southern USA. Yellow dots = museum and literature occurrence records of native populations based on Iverson (1992) and Lindeman (2013; In Press; unpubl. data); orange dot = erroneous earlier literature record (Minton 2001); red shading = projected historic distribution of G. ouachitensis ouachitensis; blue shading = G. ouachitensis sabinensis. Distribution based on GIS-defined level 12 HUCs (hydrologic unit compartments) constructed around verified localities and then adding HUCs that connect known point localities in the same watershed or physiographic region, and similar habitats and elevations as verified HUCs (Buhlmann et al. 2009; TTWG 2017), and adjusted based on subsequent data.

temperature controls part of the variability of the formation of complete crescents, the size of the post- and suborbital blotches, and the number of lines entering the orbit (Vogt 1978, 1993a; Ewert 1979), with cooler temperatures producing crescents, larger blotches, and fewer lines. Directly below the suborbital spot is another large spot on the mandible. Four large spots (at the symphysis, on each mandible, and in the center) characterize the underside of the head of $G$. o. ouachitensis.

Eye coloration does not appear to be a diagnostic feature in this species; in Wisconsin it has a white iris with a thick black horizontal line (Vogt 1981b), while in Arkansas it has a yellow iris with a dark horizontal line (Tumlison and Surf 2015). Lindeman (2003) also showed that there is much variation in iris coloration within both $G$. ouachitensis and G. pseudogeographica in Kentucky Lake. Although most specimens of G. ouachitensis had a white iris with a black line running through it, others had a white iris with no black line, and though most G. pseudogeographica had a yellow iris with no black line, some had a white iris with a black line as well, suggesting that since eye color is so variable within populations of these turtles it is not a good taxonomic feature to separate these two species. Lindeman et al. (2015) noted that iris coloration can be useful in Graptemys taxonomy; $G$. pseudogeographica from the Calcasieu River has distinctive dark pigmentation of the entire iris, causing it to appear black.

The Sabine Map Turtle, Graptemys o. sabinensis, is smaller; females reach $155 \mathrm{~mm}$ and males $106 \mathrm{~mm}$ maximum carapace length. It is differentiated from G. o. ouachitensis by having the postorbital yellow blotch reduced to an elliptical spot encircled by several concentric narrow yellow rings in most individuals. This spot is never connected to a suborbital spot to form a crescent. Six to nine yellow lines come in contact with the orbit on each side of the head. At least four of these lines are wide; this contrasts with $G$. pseudogeographica which has only narrow lines. The throat of most individuals is marked with alternating transverse yellow and dark green bars. The plastron is patterned with yellow and dark green reticulations in the center two-thirds of the plastron. The plastron of males is often flecked with black.

Hatchlings are $30 \times 30 \mathrm{~mm}$ and have a more prominent keel than the adults (Vogt 1981b). The dark plastral color 
pattern of hatchlings usually covers less than $60 \%$ of the plastron, and is confined to the area along the scute sutures (Vogt 1981b).

Several G. o. sabinensis from Old Sabine Management Area in Lindale, Texas, had the normal yellow pigmentation of the head and limbs replaced by a reddish orange coloration (Sanders et al.2010). This condition had previously only been reported in G.gibbonsi, G.oculifera, and G.versa (Buhlmann et al. 2008); however, we found this coloration to be normal in G.pseudogeographica kohnii from the Brazos River, Texas (Vogt and McCoy, unpubl. data). It is not known whether this coloration is genetic or caused by environmental influences, such as the iron red shells of Chrysemys picta in northern populations from ponds with high mineral content in the water and substrates (Vogt 1981b).

Distribution. - The northernmost range of $G$. $O$. ouachitensis reaches Dakota County, Minnesota (Oldfield and Moriarty 1994) and Lake Pepin, Pepin County, Wisconsin. Although the subspecies is abundant in the Mississippi River, it has only been found in the lower reaches near the mouths of the Black and Chippewa rivers in Wisconsin. However, it does range up the Wisconsin River as far as Portage, Wisconsin, as well as into the Cedar and Skunk rivers in Iowa, and the Illinois, Somonauk, and Fox rivers in Illinois.

The distribution in central Kentucky, eastern Illinois, Indiana, Ohio, and West Virginia is marginal and discontinuous. Populations occur in the Ohio River Basin above the Tennessee and Cumberland river mouths, in the Tradewater River in Kentucky, the Wabash River in Illinois and Indiana, the Whitewater and Great Miami riverdrainages in Indiana and Ohio, the Scioto River in Ohio, the Great Kanawha and Little Kanawha rivers in West Virginia, and the Muskingum River in Ohio.

There is only one locality in the main channel of the Missouri River (in Calloway County, Missouri), but populations are found in three of its tributaries: the Gasconade River, Marais des Cygnes River, and the Kansas River with its tributaries, the Republican River and Stranger Creek. Downstream in the Mississippi River the subspecies reaches Plaquemines Parish, Louisiana, $26 \mathrm{~km}$ from the mouth of the Mississippi River.

In Missouri this subspecies enters the Meramec, L'Anguill, St. Francis, and White rivers. In Arkansas it inhabits the Big Caney, Little Caney, Chickaskia, Pawnee, Little Arkansas, Fall, Verdigris, Neosho, South Fork of the Ninnescah, Walnut, and Cottonwood rivers. In Kansas it occurs in Labette Creek, Skeleton Creek, and the Canadian River. In Oklahoma it is found in the Illinois and Peteau rivers. In Arkansas it occurs in the Black, Ouachita, and Saline rivers. It occurs in the Red River up to Fort Still in Comanche County, Oklahoma. Tributaries of the Red River (Little, Mountain Fork, and Glover rivers) in Arkansas and Oklahoma are part of its natural range, and it also occurs in eastern Kansas. Along the Louisiana-Texas border the subspecies occurs in Caddo Lake. In Louisiana it inhabits the Atchafalaya River and two of its tributaries, Bayou Pigeon and Bayou Teche.

Graptemys o. ouachitensis is less well represented in eastern tributaries of the Lower Mississippi River, entering the Hatchie River in Tennessee and the lower Comite River in Louisiana. In Alabama it enters the Tennessee River and the Little River in Tennessee. The Cumberland River is colonized almost up to the Tennessee-Virginia border.

Graptemys o. sabinensis is restricted to the SabineNeches, Calcasieu, and Mermentau river drainages of southwestern Louisiana and adjacent eastern Texas. Lindeman (In Press) has recently documented a significant range extension northward in the Neches drainage of eastern Texas.

Habitat and Ecology. - The Ouachita Map Turtle is primarily a river turtle, although it is also found in oxbow lakes and impoundments (Lake Texoma in Oklahoma-Texas and Toledo Bend in Texas-Louisiana). It frequents the faster moving sections of the river, and can be found feeding in areas with submerged aquatic vegetation. It is noticeably absent

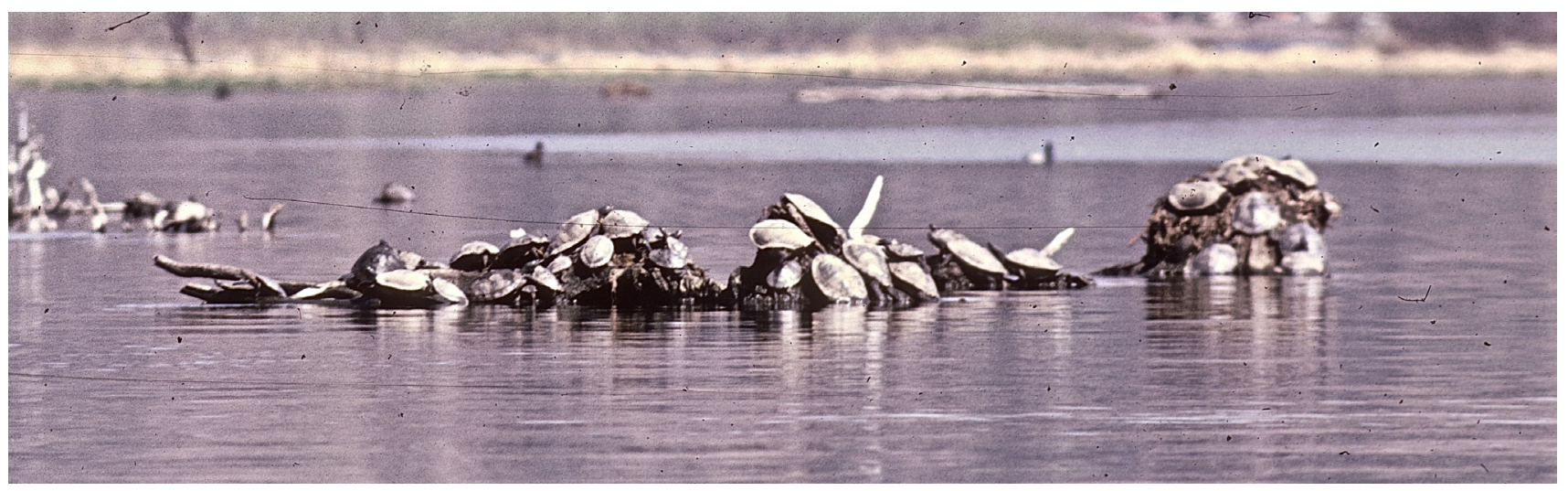

Figure 10. Basking congregation of Graptemys ouachitensis ouachitensis, Graptemys pseudogeographica, and Graptemys geographica, Stoddard, Vernon Co., Mississippi River, Wisconsin, USA. Photo by R.C. Vogt. 
from rivers that do not have submerged aquatic vegetation, e.g., the Chippewa and Black rivers of Wisconsin where it can be found only within their confluences with the Mississippi River.

Bluett et al. (2103) studied turtle assemblages of the Sangamon River in central Illinois. True river turtles (e.g., G. ouachitensis, A. mutica; Lindeman 2000) were absent from the 4th stream order, first appeared in lower reaches of the 5th, and were captured with increasing frequency in higher stream orders.

Behavior. - The species can often be seen basking on logs in mixed species groups with G. pseudogeographica and G. geographica. Basking serves several purposes: 1) it dries the shell to inhibit the growth of algae and fungi; 2) it promotes synthesis of vitamin $\mathrm{D}$ from ultraviolet radiation; 3 ) it raises body temperature to enhance digestive rates and ovulation; and 4) it presents the soft parts of the turtle to grackles that forage on attached leeches (Vogt 1979).

A Purple Grackle (Quiscalus quiscula) was observed pulling leeches from a basking G. o. ouachitensis at 1115 hrs on 9 June in Wisconsin (Vogt 1979). Placobdella parasitica is the only leech ever found on over 2000 map turtles examined from this site (Vogt 1979). These observations may document the behavior of an individual bird, as Lindeman (2013) suggested, since no one else has ever reported birds feeding on leeches from basking map turtles. It would be important to know if this was an isolated incident of one grackle learning to preen leeches from map turtles or if it is a more widespread phenomenon (Vogt 1979, 1980a).

Many animals have involved symbiotic cleaning-feeding relationships: fish, large terrestrial mammals and oxpeckers, crocodiles and sandpipers, fish and crocodiles, geckos and tortoises, crabs and finches, finches and marine iguanas (Vogt 1979). Darwin's Finches (Geospizinae) remove ticks from Galapagos Giant Tortoises (MacFarland and Reeder 1974).

Basking activity in Ouachita Map Turtles was observed from 0900 to 1800 hrs (Vogt 1980a). Up to 47 adult map turtles were observed basking together on a $6 \mathrm{~m}$ floating log; map turtles regularly bask communally on logs, stumps, and fallen trees, usually not connected to the shoreline, rarely on sandbanks (Vogt 1980a). Communal basking may be advantageous for predator detection. Turtles begin feeding in midmorning after basking and then alternate between basking and feeding throughout the day. At night they sleep on the bottom of the river (Vogt 1981b). By mid-September feeding activity has ceased in northern localities, but map turtles may still be seen basking until mid-October. Lindeman (1999b) noted that in instances of aggression within a mixed assemblage of basking turtles (G. ouachitensis, G. pseudogeographica, Pseudemys concinna, and Trachemys scripta), turtles of larger body size displaced smaller ones.
Hibernation in northern latitudes takes place under water in areas of moderate current behind logs and rock piles, spring areas, and muskrat and beaver burrows, starting in late October or early November and extending until mid-April (Vogt 1981b). Females move 4-6 km up- and downstream between hibernacula, nesting beaches, and feeding areas. Ouachita Map Turtles in the Mississippi and Wisconsin rivers behave similarly to False Map Turtles in basking, hibernating, nesting, and temperament. They have been found hibernating behind wing dams in the Mississippi River in October and November with G. geographica and G.pseudogeographica; both males and females of all three species were collected together behind a wing dam in Crosby Slough, Wisconsin (Vogt 1980a).

Diet. - Females often feed in 1 to $2 \mathrm{~m}$ of water at the surface using neustophagia, as well as beneath the surface. They appear to be opportunistic, grazing on surface vegetation and available insects. Vegetation made up $32 \%$ of volume of stomach contents from Mississippi River females in Wisconsin, consisting of pondweed (Potamogeton), duckweed (Lemna), eelgrass (Vallisneria), manna grass (Glyceria), arrowhead (Sagittaria), and algae; insects (caddisfly, mayfly, and damsel fly larvae and beetles) composed $54 \%$, fish carrion $5.2 \%$, mollusks $2.5 \%$, and $6.3 \%$ unidentified material (Vogt 1981a). Males and juveniles are more carnivorous than females, consuming only trace amounts of plant material. In Lake Texoma, a reservoir in Oklahoma, Webb (1961) found them to be feeding on midge and caddis fly larvae; ants, grasshoppers, vegetation, and bryozoans were also found in their stomach contents.

Heavy siltation in the Illinois River resulted in the change in a diet high in insects and plants to one of benthic midge larvae, but in the main channel of the river they fed on caddis fly larvae (Moll 1977). The diet of G. o. ouachitensis in the Wabash River in Illinois was similar to that of the Wisconsin population, with caddis fly larvae comprising $83 \%$ of the volume, vegetation $4 \%$, beetles $2 \%$, and snails $0 \%$ (Pierce 1992). Juveniles in a Kentucky reservoir were found to feed on snails, amphipod shrimp, milfoil, periphyton, and dipteran adults and larvae, while males fed on chironomid midge egg cases, dipteran larvae, and algae (Lindeman 1997, 2000). Small females fed on algae, bryozoans, sponges, dipteran larvae, and mayfly larvae; likewise, larger females fed on mayfly larvae, algae, and bryozoans, but also included beetles, adult dipterans, fish, and vegetation in their diet. In Wisconsin, females do not feed in the spring until after laying their first clutch of eggs in late May or early June in Wisconsin. Nesting presumably begins earlier in the South.

Courtship. - Reproductive habits of G.o.ouachitensis are similar to those of G. pseudogeographica. Male testosterone concentrations peaked in September and October in Arkansas, suggesting initiation of spermatogenesis and gonadal recrudescence, and mating in October and November 
(Pearson 2015).Copulation has not been observed in the field but probably takes place during spring and fall. Turtles taken from hibernation in November began copulating when placed in the laboratory. Courtship behavior has been observed in freshly caught males in October and November.

Males recognize conspecific females by head markings or cloacal scents (Vogt 1978). After the male determines he is with a female conspecific, he swims around to her head. $\mathrm{He}$ then places his nose against hers and simultaneously both of his forearms are arched above and in front of his head. The long claws are drummed against the tympanic regions on both sides of the female's head. This may be done from 1 to 14 times before the male attempts to mount. The probable purpose of such an act is to identify him to the female as the proper species. There is no regular number of drumming bouts given either before mating or during the drumming behavior, but the number of contacts per bout seems to be species-specific (Vogt 1978, 1980a, 1993a). In Graptemys o. ouachitensis drumming ranges from 4-8 contacts with a mean of 5.2 contacts per bout, while in $G$. pseudogeographica it ranges from 4-14 with a mean of 9.8. Possibly being drummed twice as long is sufficient for $G$. pseudogeographica females to distinguish the correct males. In addition, G. pseudogeographica males bob their heads in the vertical plane as they drum their claws while $G$. $o$. ouachitensis males do not (Vogt 1993a). The congeneric $G$. geographica does not vibrate its foreclaws but only bobs its head vertically.

Nesting and Reproduction. - Nests of G.o.ouachitensis are constructed on sandbars, islands, and beaches within $100 \mathrm{~m}$ of water; they are flask-shaped and $10-16 \mathrm{~cm}$ deep. Nesting occurs after dark or shortly after dawn. Nesting will also take place on overcast humid days, particularly just after rain storms.

Graptemyso.ouachitensis usually deposits two clutches of 6-16 (mean 10.5) flexible shelled eggs (34-38 mm x 22-26 mm) perclutch in Wisconsin (Vogt 1980a, 1981b). An estimate of average annual minimum reproductive potential would be 21 eggs with a maximum of 48 . Egg mass varies from 9.0 to $13.5 \mathrm{~g}$. Up to 4 clutches of larger but fewer eggs per clutch are laid in southern populations. A group of 107 females nesting on an island in the Mississippi River near Stoddard,Wisconsin, from 8 to 16 June 1978 laid 8-20 (mean $=12$ ) eggs per nest $(n=70)$. The females were 181-263 $\mathrm{mm}$ in straight line carapace length (mean $=208 \mathrm{~mm}$ ) and weighed 817-1929 g (mean = $1198 \mathrm{~g}$ ) (Vogt, unpubl. data). Geller (2012b) noted that initiation of nesting in this species on the lower Wisconsin River in Iowa Co. varied among years; during warmer years it began nesting as early as 23 May and in cooler years two weeks later, on 6 June.

Graptemys o. sabinensis males (to $118 \mathrm{~mm}$ in straight line carapace length) and females (to $224 \mathrm{~mm}$ ) were larger in the Mermentau and lower reaches of the Sabine and
Calcasieu river drainages than in the upper Sabine and Calcasieu drainages (to $105 \mathrm{~mm}$ and $184 \mathrm{~mm}$, respectively) (P. Lindeman, pers.comm.). Clutch sizes were also significantly larger in the Mermentau and lower Calcasieu (mean 5.3 eggs, range 3-7) compared to previously reported clutch sizes for the upper Sabine and upper Calcasieu drainages (mean 2.3 eggs, range 1-4). Comparison with recent findings for other species of Graptemys indicate that it is typical for populations in faster-current habitats to be smaller in body size (Fahrenbach et al. 2016).

Ewert et al. (2004) studied reproduction in G. $O$. sabinensis in the Calcasieu and Sabine rivers in Louisiana; by 16 May enlarged follicles were present and from 13-18 June two sets of corpora lutea were present, showing that they had laid two clutches. Recorded clutches $(n=55)$ had a mean of 2.34 eggs per clutch (range 1-4). The mean mass of $61 \mathrm{eggs}$ was $9.85 \mathrm{~g}$ and the mean mass of 94 hatchlings was $7.82 \mathrm{~g}$. Clutches containing a single egg were found in $11 \%$ of the nests. Five turtles laid clutches with four eggs. Five of the six single-egg clutches were from July, suggesting declining clutch size towards the end of the season.

There is a large difference in clutch size between $G . o$. sabinensis in Louisiana and G.o.ouachitensis in Wisconsin, where I found clutch sizes were much larger, ranging from 6-17 eggs. This is a 4.66 fold difference; Ewert et al. (2004) suggested that this is the largest difference between populations of any species of North American turtle. However, egg and hatchling mass are similaror slightly larger up North in Wisconsin at $10.9 \mathrm{~g}$ and $8.21 \mathrm{~g}$, respectively (Vogt 1981b); the smaller clutches down South in Louisiana do not have larger eggs and hatchlings as might have been expected.

Sex is determined by incubation temperature during the middle third of incubation in this species: males are produced in cooler shaded nests and from nests laid later in the season, and females in the warmer sun-exposed nests (Bull and Vogt 1979; Vogt and Bull 1984).

Eggs incubated in the laboratory produced all males at $28^{\circ} \mathrm{C}$ and $99 \%$ females at $30^{\circ} \mathrm{C}$; threshold temperature was $29.3^{\circ} \mathrm{C}$ for Wisconsin Mississippi River eggs (Bull et al. 1982a). Sex ratios of adult populations seem to be affected by incubation temperature (Bull et al. 1982b). In the Mississippi River, 4 females per male were captured in hibernacula. Combining those with turtles caught near the nesting beaches or in the feeding grounds yields an even more skewed population, with 10-20 females per male. On the other hand, in some populations in Oklahoma, Arkansas, and Louisiana the reverse ratio of 2 to 3 males per female is found (Vogt 1980a).

Hatchlings from eggs of G. o. ouachitensis incubated at $30^{\circ} \mathrm{C}$ righted more quickly than turtles incubated at $25^{\circ} \mathrm{C}$, both as hatchlings and yearlings (Freedberg et al. 2004). These results demonstrate that incubation temperature 
can have long-lasting effects on performance in turtles with temperature-dependent sex determination (TSD), and may provide the conditions required to favor the evolution of TSD. Freedberg et al. (2008) also found a significant effect of incubation temperature on circulating immune complement in hatchling G. o. ouachitensis, with maleproducing temperatures yielding the highest innate immune response. This indicated that immune response is affected by developmental temperature in a species with TSD, resulting in sex differences in the ability to fend off pathogens.

In an elegant behavioral field experiment, Pappas et al. (2017) discovered that hatchlings of three species of map turtles (G. geographica, G. ouachitensis, and $G$. pseudogeographica) on the same beach dispersed toward the near dark horizons of a forest that led them away from the river.

Predation. - Nests are preyed upon by red fox, raccoon, and otter. Geller (2012a) found raccoons destroyed $90 \%$ of 108 nests of G. o. ouachitensis on a lower Wisconsin River beach. Young raccoons, even though they are in direct contact with nesting females, will opt to leave the females alone and just gorge on eggs (Geller 2014). Larval fly predation is also responsible for the mortality of many eggs; fly larvae (Sarcophagidae) enter pipped eggs or eat their way into the living egg and eat the hatchling turtle alive before it leaves the egg (Vogt 1979, 1981c). Hatchlings are consumed by many birds (ring-billed gulls, crows, grackles, and redwinged black birds) and fish. Humans are the main cause of death of adults; in the North, commercial fishermen setting gill nets for capturing carp are responsible for the death of untold numbers of adult females in the Mississippi River, and in the South basking turtles are shot for sport with low caliber rifles (Vogt 1978, 1981a, pers. obs.).

Competition. - East and Ligon (2013) found a greater overlap in food items consumed by reintroduced juvenile Macrochelys temminckii and native adult female G. $o$. ouachitensis, than in areas where they were living in natural syntopy, where there was less dietary overlap, suggesting that captive raised turtles take time to assimilate with the native populations of turtles where they are introduced. Possible displacement of G.o.ouachitensis was observed where $M$. temminckii was reintroduced into small rivers in northern Oklahoma (Anthony 2013).

Population Status. - Populations are abundant and doing well in the Mississippi and Wisconsin rivers in Wisconsin. Populations in southwest Indiana were reported to be viable in 1984 (M. Ewert, pers. comm.). The marginal populations in Ohio and West Virginia were so low that they need to be verified whether they are still present (Vogt 1993b). Surveys in Illinois by Moll (1977) found populations to be abundant in some areas but feeding on impoverished food resources in others. Surveys in Arkansas, Oklahoma, Texas, and Louisiana from 1974 to 1979 found them to be abundant in most localities where they would be expected to occur (Vogt and C.J. McCoy, unpubl. data).

Tinkle (1958) found G. ouachitensis to make up $12 \%$ of the six-turtle assemblage he studied on the Tensas River in Louisiana, third in relative abundance following $G$. pseudogeographica and Trachemys scripta. Although no $G$. ouachitensis were collected in baited traps in the Mississippi River in Illinois where 283 turtles of seven species were collected, it does not mean they were not there (Anderson et al.2002); this species is rarely captured in baited hoop traps, even in areas where they are abundant (Vogt 1980b). The species is more easily collected by other methods of trapping, i.e., fyke nets and trammel nets. Graptemys ouachitensis was collected along with a mix of G. pseudogeographica in $9 \%$ of the catch of seven species from fyke nets set in the Mississippi River in Iowa, but the $9 \%$ could have been all G. pseudogeographica or all G. ouachitensis since the investigators were not able to distinguish the two species (Gritters and Mauldin 1994). The successful use of fyke and trammel nets in the Mississippi River upstream from the mouth of the Ohio River demonstrated the effectiveness of these methods for this species: $82 \%$ of the catch of six species was G. ouachitensis (Barko et al. 2004).

Pierce (1992) found this species to be the third most abundant species, $15 \%$ of the turtles captured in trammel and fyke nets, and baited hoop traps set in the Wabash River in Illinois. In Kansas, Fuselier and Edds (1994) reported $G$. ouachitensis to be the third most abundant species, $11 \%$ of the total of ten species captured in baited hoop traps set in 41 counties. If fyke nets had been used, these numbers would have been different; inadequate trapping techniques obscure the abundance of this species. A similar ranking of third, $12 \%$ of the species caught in the Kansas River, was reported by Busby and Parmenter (1996). Baited hoop traps set in tributary creeks of the Arkansas River in Sequoyah National Wildlife Refuge in Oklahoma produced only $3.7 \%$ G. ouachitensis, though it was the third most abundant of the nine species captured (Riedle et al. 2008). In Eastern Oklahoma it was second only to T. scripta, $8 \%$ in abundance of a total of 13 species captured in hoop traps (Riedle et al. 2009). Methods of using traps, as well as the shape and size of the trap perhaps influences the capture of these species and confounds actual population status; only one G.ouachitensis was among the 723 turtles of seven species captured in the floodplain backwaters of the Mississippi River in southern Missouri (Wallace et al. 2007).

Basking surveys are perhaps a much more reliable method for determining the abundance of this species, and other species that are habitual baskers, provided the observer is able to distinguish this species from other map turtles. The best published basking studies were by Peter Lindeman and John Carr. Lindeman (2013) found that the mean basking density was $25 \mathrm{G}$. ouachitensis per $\mathrm{km}$ of shoreline in both 
Kentucky Lake and the Tennessee River. Ouachita Map Turtles comprised $27 \%$ of the turtles seen basking in spotting scope surveys and $29 \%$ of the turtles captured in fyke nets and basking traps, the second most abundant of 11 species captured, after T. scripta (Lindeman 1999a). In smaller rivers this species is much less abundant; in another Kentucky small river, the Tradewater River, only 2 G. ouachitensis were counted in a sample of 344 basking turtles, $<1 \%$ of the turtles recorded, and the 6th most abundant (3rd rarest) of the eight species present.

Although basking surveys are rather new to turtle sampling techniques, first used by Vogt and McCoy in the late 1970s, when combined with fyke net capture data, concrete indices of map turtle populations can be estimated quite accurately. Populations of other species which bask only rarely are harder to make meaningful population estimates for from basking surveys, just like baited hoop traps underestimate map turtle populations.

Carr (2001) conducted basking surveys in 17 habitats in northern Louisiana from 1998 to 2000. Ouachita Map Turtles were seen at four localities, making up $14 \%$ of the 552 emydid turtles recorded. The highestrelative abundances were in the Red $(57 \%)$ and the Ouachita (16\%) rivers.Density of basking G. ouachitensis ranged from 4 to 85 per km of river shoreline (Carr 2001).

In southern Louisiana, Ilgen et al. (2014) found Sabine Map Turtles to be the most abundant turtle in the Mermentau River drainage (73\% of turtles documented). During basking surveys they observed densities of 14 to 35 G. o. sabinensis per river km in the Mermentau and Bayou Plaquemine Brule rivers. Bayous des Cannes and Nezpique and Lake Arthur had lower densities, 5-10 G.o.sabinensis per river km; while the river below Lake Arthur and the southern tributaries, Bayou Queue de Tortue and Lacassine Bayou, had only 1-2 G. o. sabinensis per river km.

Triplett (2016) surveyed the trans-Mississippi region of western Louisiana and reported a total of 3594 turtles basking; she was able to identify $80 \%$ of these to species. Graptemys o. ouachitensis was observed at 38 unique sites west of the Mississippi River and comprised $6.8 \%$ of all turtles observed. Observations of G. o. ouachitensis were concentrated in bodies of water with a high flow rate, in main channels of larger order lotic systems (Ouachita, Boeuf, Black, and Red rivers), but in relatively few tributary streams (Bayou Bartholomew and Saline Bayou).Graptemys o.ouachitensis was also found in naturally occurring floodplain oxbows (Yucatan Lake and Moon Lake), or cutoffs from the main channels made for the purpose of maintaining navigation channels by the US Army Corps of Engineers (Lake Bartholomew and numerous Red River lakes). Graptemys o. sabinensis was observed at seven unique sites in two water bodies, the Sabine River and Whiskey Chitto Creek; it was not observed in the only lake surveyed within its range, Toledo Bend Reservoir.
Coleman and Gutberlet (2008) conducted basking surveys of G. o. sabinensis along a $1.5 \mathrm{~km}$ transect of the Sabine River in Smith County, Texas; they found 2761 males and 1334 females basking, with basking activity peaking in May with a peak of lesser magnitude in November. Significantly more males than females were recorded basking throughout the year. This contrasts to G. o. ouachitensis where significantly more females than males were observed basking on the Mississippi River in Wisconsin (Vogt 1981a).

In basking surveys on tributaries of the Arkansas River in northeastern Oklahoma, Lindeman (2015) identified 377 turtles; $57 \%$ were G. o. ouachitensis. The other major component was Trachemys scripta with 26\%. These two predominant species each occurred at more than $70 \%$ of sites. Four other species (Apalone spinifera, Pseudemys concinna, G.pseudogeographica, and G.geographica) each comprised no more than $6 \%$ of the total sample.

Visual basking surveys provide rapid, wide-ranging assessments of the status of turtle species that commonly engage in basking, such as Graptemys (Vogt 2012). To generate sample sizes of captured turtles comparable to those of a short study of a few days, several weeks of trapping would be necessary.

Threats to Survival. - Populations are stable in the northern part of the range where humans do not prey upon them and pollution of the rivers is held in check. In the south they are collected and eaten, primarily in Louisiana,Arkansas, and Tennessee. More adult females die inadvertently in the nets of commercial fishermen in the Mississippi River than are taken by people in the South to eat. Their sale was limited to a few biological supply houses, most of which have now been closed down in Wisconsin. But since demand is not high, this does not seem to be a problem.

The greatest threats to the survival of this species are destruction of nesting habitat and nests by agricultural practices and camping tourists and pollution of the water they live in, as well as the looming threat of inadequate laws allowing commercial collection and exportation for food to China and East Asia. Also, many local residents in the South shoot basking turtles with rifles for sport.

Neuman-Lee and Janzen (2011) provided experimental evidence that G.o.ouachitensis and G.pseudogeographica hatchlings are adversely affected after only minimal exposure to low concentrations of atrazine during embryonic development. Atrazine is one of the most widely applied herbicides used in the world, and has been shown to negatively affect many species of wildlife. Van Dyke et al.(2013) tested differences in selenium uptake related to the trophic level and feeding preferences of turtles, including G.o.ouachitensis, near the site of the Kingston coal fly-ash spill in Tennessee.

Conservation Measures Taken. - In the Upper Mississippi River Wildlife Refuge in Vernon County, 
Wisconsin, the USFWS has been building islands for duck and turtle nesting habitat since 2011 (Vogt, pers. obs.). The islands have been built to be permanent, with a rip-rap base covered with dredge spoil sand; they are shaped like crab claws, which offers a physical structure to capture sand and silt to continue the building process, and a shallow backwater area as a nursery for hatchling turtles and ducklings. The oldest islands were only a year old when map and softshell turtles were already observed nesting, indicating that turtles do not always return to nest on the beach where they hatched (Vogt, unpubl. data). The USFWS was planning on building 50 such islands, with 14 already built. Nesting islands away from the riverbanks should diminish predation of the nesting females, their eggs and their hatchlings from mammalian predators.

New channels dug to straighten the Mermentau River and the lower Bayou Plaquemine Brule in Louisiana, together with dredging that has maintained the connections to the original channels, has increased riverine habitat for Sabine Map Turtles and other turtle species in the drainage, and may help to maintain larger populations than would be present in the river without the cut-offs (Hartson et al. 2014).

Populations of map turtles can be increased more rapidly by creating more female-producing beaches: hotter open beaches where the incubation temperature is higher in order to produce more female hatchlings (Vogt and Bull 1984). Males can fertilize many females and the sex ratio is highly imbalanced naturally in the favor of females on the Mississippi River, at least 4 to 5 females per male, and there is no problem with fertility in the clutches of eggs that are being laid. Manipulating sex ratios for the short term, 20-50 years, by increasing the production of females, will augment the population much more rapidly than producing males (Vogt 1994).

The Department of Natural Resources banned the biological supply house industry in Wisconsin from commercial collecting of all animals for sale, particularly turtles, in 2004; they also limited the number of traps commercial turtle trappers could use, though map turtles rarely enter hoop traps. These regulations have stopped commercial turtle trapping in Wisconsin. Maintenance of basking logs near nesting islands is necessary, since G. $o$. ouachitensis is very wary and does not generally bask on logs or branches connected to the shoreline of the river. Commercial fishermen using gill nets should be prohibited from setting nets within $2 \mathrm{~km}$ of turtle nesting beaches to avoid drowning of adult female turtles.

Experiments investigating the potential for reducing turtle nest predation by racoons by eliminating surface markings by broom sweeping nesting areas were conducted at G.o.ouachitensis nesting sites along the lower Wisconsin River in Iowa County, Wisconsin (Geller 2015). Findings suggested that broom sweeping was ineffective because the location cues used by raccoons to find newly constructed nests are not primarily visual, but olfactory, and related to soil profile disturbance, possibly via the microbial metabolite geosmin.

Conservation Measures Proposed. - Establishment of a nesting island in the Mississippi River near Stoddard, Wisconsin, is proposed as a recognized Scientific Area by the State. In the South, an education program needs to be developed to curtail the sport shooting of turtles. Posters should be designed explaining in simple diagrammatic terms and drawings to attract attention, why it is beneficial for hunters and fishermen not to shoot basking turtles.

Since the Sabine Map Turtle is found only in three isolated drainages, population levels should be monitored at regular intervals to insure that it is not threatened by environmental or other impacts.

Captive Husbandry. - This species grows and reproduces well in captivity at temperatures of $25-30^{\circ} \mathrm{C}$. It thrives on a diet of canned sockeye salmon, but would probably grow equally well on crab or lobster. It can be grown to reproductive size in eight years for females and four years for males and produce fertile eggs on a diet of Purina trout chow mixed with bone meal, oyster shells, cod liver oil, multiple vitamins, all held together in an agar gelatin base (Vogt 1980a). I maintained a colony of 86 turtles, originally hatchlings, for 15 years on such a diet. Later they were fed only dry dogfood for 5 years. Growth rates of males and females were the same for the first three years, then the growth rate of males began to taper off with the onset of sexual maturity (Vogt 1980a). This species is very sensitive to lack of sunlight; if direct sunlight cannot be offered then Vitalite or some other source of ultraviolet radiation must be provided. Basking areas where they can get completely out of the water and dry off are also essential for the health of this species in captivity. Ouachita Map Turtles, like many hatchling turtles, are highly susceptible to infections of Citrobacter freundii; characterized by swollen and closed eyelids and an eventual degeneration of the carapace. Chloromycetin dissolved in the water proved to be an effective treatment for infected hatchlings, but intramuscular injections resulted in high mortality.

Current Research. - My research with this species in Wisconsin from 1971-78, and to a lesser extent in Arkansas, Oklahoma, Texas, and Louisiana, produced much of what is known about this species, both ecologically and taxonomically (Vogt 1978, 1979, 1980a). Bull and Vogt (1979, 1981), Bull et al. (1982a,b), and Vogt and Bull (1982, 1984) studied aspects of environmental sex determination. Ewert (1979) conducted many incubation experiments with this species.

Presently Fred Janzen of Iowa State University is studying the relationship between temperature and genetics of the head markings, extending the study of Vogt (1978) 
with eggs from the Mississippi river population at Stoddard, Wisconsin.Geller(2012a,b) has continued to study the nesting ecology and effect of predator control on nest survivorship in this species in nesting beaches along the lower Wisconsin River in Iowa County.

In the South, Peter V. Lindeman and John L. Carr are pursuing detailed ecological and population studies, particularly in the Calcasieu and Mermentau rivers in southern and northern Louisiana, respectively. Detailed river-by-river drainage population surveys are lacking for the northeastern part of the range of this species, particularly in Ohio and West Virginia.

Acknowledgments. - I thank Peter V. Lindeman for providing new information on the distribution of $G$. $O$. sabinensis in the Neches drainage of eastern Texas and for providing unpublished locality points for G.o.ouachitensis. I also thank him and Bruce Brecke for the use of their photos of both subspecies. The University of Wisconsin-Madison Zoology Department Jefferson Davis Fund and Zoological Museum, Carnegie Museum of Natural History, Pittsburgh, and Wisconsin Department of Natural Resources helped to fund my field work on the Mississippi River and I was assisted in the field by Maxine Binn, Marsha Christianson, George Dmytrenko, Janis Dzlzkalns, Shelly Fost, Bruce Hellmich, Jeremy Jacobs, Alan Jaslow, Kristine Klevickis, Lisa Mattick, Patricia Morton, Donna Nelson, Michael Pappas, Dan and Robert Peterson, and Jack Roberts.

\section{LITERATURE CITED}

Anderson, R.A., Gutierrez, J.L., And Romano, M.A. 2002. Turtle habitat use in a reach of the upper Mississippi River. Journal of Freshwater Ecology 17:171-177.

ANTHONY,T.L.2013.Aquatic turtle community dynamics in relation to reintroduction of Alligator Snapping Turtles, Macrochelys temminckii. Masters Thesis, Missouri State University,

Barko, V.A., Briggler, J.T., AND Ostendorf, D.E. 2004. Passive fishing techniques: a cause of turtle mortality in the Mississippi. Journal of Wildlife Management 68:1145-1150.

Beyer, G.S. 1900. Louisiana herpetology. Proceedings of the Louisiana Society of Naturalists 1897-1899:24-46.

Bluett, R.D., Louis, W.E., Newhouse, D.A., Handel, C.J., JR., AND KuBE, J.H. 2013. Longitudinal structuring of turtle assemblages in an altered river in Central Illinois, USA: implications for conservation. Transactions of the Illinois State Academy of Science 106:47-53.

Brown, A.D., Temple-Miller, K., Roosenburg, W.M., And White, M.M. 2012. Mitochondrial DNA variation in the Ouachita Map Turtle. Copeia 2012:301-306.

Buhlmann, K.A.,Tuberville, T., and GibBons,J.W.2008. Turtles of the Southeast. Athens, GA: University of Georgia Press, 264 pp.

Buhlmann, K.A., Akre, T.S., Iverson, J.B., Karapatakis, D., Mittermeir,R.A.,Georges,A.,Rhodin,A.G.J., van DiJk,P.P., AND GiBBons, J.W. 2009. A global analysis of tortoise and freshwater turtle distributions with identification of priority conservation areas. Chelonian Conservation and Biology 8:116-149.
Bull, J.J. And Vogt, R.C. 1979. Temperature dependent sex determination in turtles. Science 206(4423):1186-1188.

Bull, J.J. And Vogt, R.C. 1981. Temperature sensitive periods of sex determination in emydid turtles. Journal of Experimental Zoology 218:435-440.

Bull, J.J., Vogt, R.C., ANd McCoy, C.J. 1982a. Sex determining temperature in turtles: a geographic comparison. Evolution 36:326-332.

Bull, J.J., Vogt, R.C., ANd Bulmer, M.G. 1982b. Heritability of sex ratio in turtles with environmental sex determination: a geographic comparison. Evolution 36:333-341.

Busby, W.H. And Parmelee, J.R. 1996. Historical changes in a herpetofaunal assemblage in the Flint Hills of Kansas. American Midland Naturalist 135:31-91.

CAGLE, F.R. 1953. Two new subspecies of Graptemys pseudogeographica. Occasional Papers of the Museum of Zoology of the University of Michigan 546:1-17.

CARr, J.L. 2001. Louisiana Map Turtle Survey: Map Turtles in Northern Louisiana. Unpublished report to the U.S. Geological Survey-Biological Resources Division, Cooperative Agreement No. 99CRAG0017.

Cochran, D.M. and Goin, C.J. 1970. The New Field Book of Reptiles andAmphibians. New York: G.P.Putnam's Sons, 359 pp.

Coleman, J.L. AND GutBerlet, R.L., JR. 2008. Seasonal variation in basking in two syntopic species of map turtles (Emydidae: Graptemys). Chelonian Conservation and Biology 7:276-281.

EAST, M.B. AND Ligon, D.B. 2013. Comparison of diet among reintroduced and wild juvenile Alligator Snapping Turtles (Macrochelystemminckii) and adult female Ouachita Map Turtles (Graptemys ouachitensis). Southwestern Naturalist 58:450-458.

EWERT, M.A. 1979. Graptemys pseudogeographica ouachitensis (Ouachita map turtle). Geographic distribution. Herpetological Review 10:102.

Ewert, M.A., Doody, J.S., AND CARr, J.L. 2004. Graptemys ouachitensis sabinensis (Sabine map turtle). Reproduction. Herpetological Review 35:382-383.

Fehrenbach, A.K., Louque, I., McFadden, S.L., Huntzinger, C., Lyons, E., Shively, S.H., Selman, W., and Lindeman, P.V. 2016. Habitat-related variation in body size and reproductive output and an examination of reproductive allometry in the Sabine Map Turtle (Graptemys sabinensis) across three river drainages. Copeia 104:458-468.

Freedberg, S., Stumpf, A.L., Ewert, M.A., and Nelson, C.E. 2004. Developmental environment has long-lasting effects on behavioural performance in two turtles with environmental sex determination. Evolutionary Ecology Research 6:739-747.

Freedberg, S.T., Greives, J., Ewert, M.A., Demas, G.E., Beecher, N., AND Nelson, C.E. 2008. Incubation environment affects immune system development in a turtle with environmental sex determination. Journal of Herpetology 42:536-541.

FusEliER, L. AND EDDS, D. 1994. Habitat partitioning among three sympatric species of map turtles, genus Graptemys. Journal of Herpetology 28:154-158.

Geller, G.A. 2012a. Notes on the nest predation dynamics of Graptemys at two Wisconsin sites using trail camera monitoring. Chelonian Conservation and Biology 11:197-205.

Geller, G.A. 2012b. Notes on the nesting ecology of Ouachita map turtles (Graptemys ouachitensis) at two Wisconsin sites using trail camera monitoring. Chelonian Conservation and Biology 11:206-213.

GELLER,G.A.2014.Graptemys ouachitensis(Ouachita Map Turtle). Interaction with predator. Herpetological Review 45:484-485.

GELLER, G.A. 2015. A test of substrate sweeping as a strategy to 
reduce raccoon predation of freshwater turtle nests, with insights from supplemental artificial nests. Chelonian Conservation and Biology 14:64-72.

Gritters, S.A. and Mauldin, L.M. 1994. Four years of turtle collections on navigation pool 13 of the Upper Mississippi River. Unpublished report LTRMP94-S010 of the Iowa Dept. of Natural Resources for the National Biological Survey, Environmental Management Technical Center, Onalaska, Wisconsin.

Hartson, C.A., Ilgen, E.L., Zaleski, O.S., and Lindeman, P.V. 2014. Effects of channelization on Sabine Map Turtle habitat in the Mermentau River drainage, Louisiana; use of original vs. new channels. Southeastern Naturalist 13:119-127.

Ilgen, E.L., Hartson, C.A., Zaleski, O.S., and Lindeman, P.V. 2014. Map turtles of the Mermentau: status surveys of forgotten populations. Chelonian Conservation and Biology 13:1-8.

IVERSON, J.B. 1992. A Revised Checklist with Distribution Maps of the Turtles of the World.Richmond, IN: Privately printed, $363 \mathrm{pp}$.

Lamb, T., Lydeard, C., Walker, R.B., And Gibbons, J.W. 1994. Molecular systematics of map turtles (Graptemys): a comparison of mitochondrial restriction site versus sequence data. Systematic Biology 43:543-559.

Lindeman, P.V. 1997. A comparative spotting-scope study of the distribution and relative abundance of river cooters (Pseudemys concinna) in western Kentucky and southern Mississippi. Chelonian Conservation and Biology 2:378-383.

Lindeman, P.V. 1999a. Surveys of basking map turtles Graptemys spp. in three river drainages and the importance of deadwood abundance. Biological Conservation 88:33-42.

Lindeman, P.V. 1999b. Aggressive interactions during basking among four species of emydid turtles. Journal of Herpetology 33:214-219.

Lindeman, P.V. 2000. Resource use of five sympatric turtle species: effects of competition, phylogeny, and morphology. Canadian Journal of Zoology 78:992-1008.

Lindeman, P.V. 2003. Diagnostic characteristics in lower Tennessee River populations of the map turtles Graptemys pseudogeographica and Graptemys ouachitensis. Chelonian Conservation and Biology 4:564-568.

Lindeman, P.V. 2013. The Map Turtle and Sawback Atlas: Ecology, Evolution, Distribution, and Conservation. Norman, OK: University of Oklahoma Press, 460 pp.

Lindeman, P.V. 2015. Surveys of basking turtles in the rivers of northeastern Oklahoma, with emphasis on Graptemys geographica (Common Map Turtle). Proceedings of the Oklahoma Academy of Sciences 94:1-9.

Lindeman, P.V. In Press. Map turtles of the upper Neches River drainage in East Texas. Southwestern Naturalist.

Lindeman, P.V., Louque, I., Huntzinger, C., Lyons, S.E., Shively, S.H., AND Selman,W. 2015. Eye color and chin pattern in the turtle Graptemys pseudogeographica in the Calcasieu River Drainage of Louisiana, with comparison to adjacent drainages. Herpetological Review 46:179-185.

MacFarland, C.G. And ReEder, W.G. 1974. Cleaning symbiosis involving Galapagos tortoises and two species of Darwin's finches. Zeitschrift für Tierpsychologie 34:464-483.

Minton, S.A.,JR. 2001.Amphibians and Reptiles of Indiana, Second Edition. Indianapolis: Indiana Academy of Science, 404 pp.

Moll, D. 1977. Ecological investigations of turtles in a polluted ecosystem: the Central Illinois River and adjacent flood plain lakes. Ph.D. Thesis, Illinois State University, Normal.

MYers, E.M. 2008. Post-orbital color pattern variation and the evolution of a radiation of turtles (Graptemys).Ph.D.Dissertation, Iowa State University, Ames.
Neuman-Lee,L.A. And JAnZEN,F.J.2011.Atrazine exposure impacts behavior and survivorship of neonatal turtles. Herpetologica 67:23-31.

Oldfield, B. and Moriarty, J.J. 1994. Amphibians and Reptiles Native to Minnesota. Minneapolis: University of Minnesota Press, $237 \mathrm{pp}$.

Pappas, M.J., Congdon, J.D., And BRecke, B.J. 2017. Orientation in five species of hatchling river turtles dispersing from experimental nests. Chelonian Conservation and Biology 16:3-11.

Pearson, L. 2015. Seasonal corticosterone and gonadal steroid concentrations of the Ouachita Map Turtle (Graptemys ouachitensis) in the Arkansas River. Masters Thesis, University of Central Arkansas, Conway.

PierCe, L. 1992. Diet content and overlap of six species of turtle along the Wabash River. Masters Thesis, Eastern Illinois University, Charleston.

Praschag, P., Ihlow, F., Flecks, M., Vamberger, M., and Fritz, U. 2017. Diversity of North American map and sawback turtles (Testudines: Emydidae: Graptemys). Zoologica Scripta 46: 675-682.

Riedle, J.D., Shipman, S.F., Fox, S.F., Hackler, J.C., ANd Leslie, D.M. 2008. Population structure of the alligator snapping turtle, Macrochelys temminckii, on the western edge of its distribution. Chelonian Conservation and Biology 7:100-104.

Riedle, J.D., Shipman, S.F., Fox, S .F., AND Leslie,D.M. 2009. Habitat associations of aquatic turtle communities in eastern Oklahoma. Proceedings of the Oklahoma Academy of Science 89:19-30.

SANDERS, S.A.,Coleman, J.L., AND PlacyK, J.S.,JR.2010.Graptemys ouachitensis sabinensis (Sabine Map Turtle). Coloration. Herpetological Review 41:214.

StePhENS, P.R. AND WIENS, J.J. 2003. Ecological diversification and phylogeny of emydid turtles. Biological Journal of the Linnean Society 79:577-610.

Stephens, P.R. AND Wiens, J.J. 2004. Convergence, divergence, and homogenization in the ecological structure of emydid turtle communities: the effects of phylogeny and dispersal. American Naturalist 164:244-254.

Thomson, R.C., SPInKs, P.Q., AND SHAFFER, H.B. 2018. Molecular phylogeny and divergence of the map turtles (Emydidae: Graptemys). Molecular Phylogenetics and Evolution 121:61-70.

TINKLE, D.W. 1958. Experiments with sampling southern turtle populations. Herpetologica 14:172-175.

Triplett, A.N. 2016. Distribution and habitat use of map turtles (Graptemys) in the trans-Mississippi region of Louisiana. M.Sc. Thesis, University of Louisiana at Monroe.

TTWG [Turtle TAXonomy Working Group] [Rhodin, A.G.J., Iverson, J.B., Bour, R. Fritz, U., Georges, A., Shaffer, H.B., AND van DiJK, P.P.]. 2017. Turtles of the World: Annotated Checklist and Atlas of Taxonomy, Synonymy, Distribution, and Conservation Status (8th Ed.). In: Rhodin, A.G.J., Iverson, J.B., van Dijk, P.P., Saumure, R.A., Buhlmann, K.A., Pritchard, P.C.H., and Mittermeier, R.A. (Eds.). Conservation Biology of Freshwater Turtles and Tortoises: A Compilation Project of the IUCN/SSC Tortoise and Freshwater Turtle Specialist Group. Chelonian Research Monographs 7:1-292.

Tumlison, R. And SuRf, A. 2015. Atypical head markings of the Ouachita Map Turtle (Graptemys ouachitensis) in the Upper Ouachita River of Arkansas. Journal of the Arkansas Academy of Science 69:157-160.

VAN DyKe, J.U., Hopkins, W.A., AND JACKSON, B.P. 2013. Influence of relative trophic position and carbon source on selenium bioaccumulation in turtles from a coal fly-ash spill site. Environmental Pollution 182:45-52. 
VoGt,R.C.1974.Systematics of the Graptemys pseudogeographica complex (Abstract). Herpetological Review 5:79. .

VoGt, R.C. 1978. Systematics and ecology of the false map turtle complex Graptemys pseudogeographica. Ph.D. Dissertation, University of Wisconsin-Madison.

VoGT, R.C. 1979. Cleaning/feeding symbiosis between Grackles (Quiscalus: Icteridae) and Map Turtles (Graptemys: Emydidae). Auk 96:608-609.

VoGT, R.C. 1980a. Natural history of the map turtles Graptemys pseudogeographica and Graptemys ouachitensis in Wisconsin. Tulane Studies in Zoology and Botany 22:17-48.

VoGT, R.C. 1980b. New methods for trapping aquatic turtles. Copeia 1980:368-371.

VoGT, R.C. 1981a. Food partitioning in three sympatric species of map turtles, genus Graptemys (Testudinata,Emydidae).American Midland Naturalist 105:102-111.

VoGT, R.C. 1981b. Natural History of Amphibians and Reptiles in Wisconsin.Milwaukee, WI: Milwaukee Public Museum, 205 pp.

VoGT, R.C. 1981c. Turtle egg (Graptemys: Emydidae) infestation by fly larvae. Copeia 1981:457-459.

VoGt, R.C. 1993a. Systematics of the false map turtle (Graptemys pseudogeographica complex: Reptilia, Testudines, Emydidae). Annals of Carnegie Museum of Natural History 62:1-46.

Vogt,R.C.1993b.Graptemys ouachitensis. Catalogue of American Amphibians and Reptiles 603.1-4.

VoGT, R.C. 1994. Temperature controlled sex determination as a tool for turtle conservaton. Chelonian Conservation and Biology 1:159-162.

Vogt, R.C. 1995. Graptemys ouachitensis Cagle: Ouachita map turtle. Catalogue of American Amphibians and Reptiles 603.1-4.

Vogt, R.C. 2012. Detecting and capturing turtles in freshwater
habitats.In: McDiarmid, R.W.,Foster, M.S.,Guyer,C., Gibbons, J.W., and Chernoff, N. (Eds.). Reptile Biodiversity: Standard Methods for Inventory and Monitoring. Berkeley: University of California Press, pp. 181-187.

Vogt, R.C. And Bull, J.J. 1982. Temperature controlled sexdetermination in turtles: ecological and behavioral aspects. Herpetologica 38:156-164.

Vogt, R.C. AND BuLL, J.J. 1984. Ecology of hatching sex ratio in map turtles. Ecology 65:582-587.

Wallace,J.E.Z.,Fratto, W., And BarKo, V.A. 2007.Acomparison of three sampling gears for capturing aquatic turtles in Missouri: the environmental variables related to species richness and diversity. Transactions of the Missouri Academy of Science 41:7-13.

Weвв, R.G. 1961. Observations on the life histories of turtles (genus Pseudemys and Graptemys) in Lake Texoma, Oklahoma. American Midland Naturalist 65:193-214.

WiENs, J.J., KuCZYNSKi, C.A., AND StePHENs, P.R. 2010. Discordant mitochondrial and nuclear gene phylogenies in emydid turtles: implications for speciation and conservation. Biological Journal of the Linnean Society 99:445-461.

\section{Citation Format for this Account:}

Vogt, R.C. 2018. Graptemys ouachitensis Cagle 1953 - Ouachita Map Turtle. In: Rhodin, A.G.J., Iverson, J.B., van Dijk, P.P., Buhlmann,K.A.,Pritchard,P.C.H., and Mittermeier,R.A.(Eds.). Conservation Biology of Freshwater Turtles and Tortoises: A Compilation Project of the IUCN/SSC Tortoise and Freshwater Turtle Specialist Group. Chelonian Research Monographs 5(11):103.1-13. doi: 10.3854/crm.5.103 .ouachitensis.v1.2018; www.iucn-tftsg.org/cbftt/. 